\title{
A Preliminary survey of Dipterans in Sindhudurg District, Maharashtra, India
}

\author{
D. L. Bharamal* \\ Department of Zoology, Shri Panchamkhemraj Mahavidyalaya Savantvadi 416 510, MS, India \\ *Corresponding author
}

Keywords

Preliminary survey, Dipterans,

Article Info

Accepted:

16 December 2015

Available Online:

10 January 2016

\section{A B S T R A C T}

The present preliminary study is on Diptera of Sindhudurg district, in which five major localities were selected viz. Sawantwadi, Amboli, Malvan, Kudal and Kankavli. The present study, includes 34 dipterans (Psychodidae, Culicidae, Chironomidae, Cecidomyiidae, Tabanidae, Asilidae, Trypetidae, Agromyzidae, Drosphilidae, Muscidae, Anthomyiidae, Calliphoridae, Sarcophagidae, Tachinidae, Oestridae and Hippobiscidae).

\section{Introduction}

The Diptera are commonly known as true flies. The dipterans being the largest group with more than 100,000 species (Saha, 2012). Saha (2012) has recorded 278 species under 157 genera under 36 families excluding Cecidomyiidae and Tabanidae from Maharashtra. Sharma (2012) has reported 18 species of Tabanidae and 90 species of Cecidomyiidae from Maharashtra.

The present communication contains records of localities of the relatively well known species, comprising of 34 species belonging to 26 genera under 16 families. The Diptran of Sindhudurg district is relatively unknown. To better understanding the diversity and ecology of this endangered habitat, the
Dipteran fauna of Sindhudurg district was surveyed with the goal of providing baseline data for conservation and restoration efforts as well as for future ecological studies.

\section{Materials and Methods}

\section{Study Area}

The Sindhudurg district comes under Konkan zone and lies between 15037' North to 1640 North latitude and 73019' East to 74013' East longitude. The total area of the district is 5087.5 sq. $\mathrm{km}$. The forests in the district cover an area about 409.06 sq.km under the Forest Department, out of which 285.45 sq.km in Savantvadi and 
Kudaltalukas and 12.61 sq.km in remaining talukas.The district is surrounded by Ratnagiri district in the north Sahyadri hills and beyond Sahyadri, Kolhapur district, the state of Goa in south and Arabian Sea towards the west. Physiographical this area is rugged and complex one. The height of the region varies from sea level up to 1300 m.

\section{Results and Discussion}

Diptera is represented by 34 species distributed over 26 genera belonging to 16 families. The family Cecidomyiidae and Calliphoridae was found to be dominant family containing 5 species. The families Culicidae, Trypetidae andAnthomyiidae are represented by 3 species each while families Tabanidae, Asilidae, Muscidae and Hippobiscidae are represented by 2 species each. The families Psychodidae, Chironomidae, Agromyzidae, Drosophilidae, Sarcophagidae, Tachinidae and Oestridae showed presence of single species. More or less similar results were made by Mariappanet al., (1997) they reported 35 species of Diptera from Kochi and its adjoining Islands, Kerala. However, Sharma et al, (2008) reported 6 species of Dipterans from Chandrabhagariver, Garwal, Himalayas. Rajput and Kulkarni (1990) reported 31 species of mosquitoes. Similarly Rajput and Singh (1991) reported 13 species of mosquitoes with reference to Culicidae from Manipur from the rural areas of Mysore and Mandya, Karnataka 29 species of mosquitoes were recorded by Kumar and Vijayan (2005). Tingare (2007) enlisted 22 species of mosquitoes from Southern Maharashtra, India. While in the present study only three species of culicidae were reported. Nandi (1990) reported 11 species of Sarcophagid flies from Tamil Nadu and Kerala. In the present study single species Sarcophagasp. was observed. Ranganath and Veenakumari (1996) reported 11 species of fruit flies from Andaman and Nicobar Islands. According to Grimaldi and Engel (2005) about 120,000 species of Diptera were enlisted worldwide. As far as number of Dipteran species recorded during the study indicated this order is poorly represented in the study region.

\section{Order: Diptera}

\section{Family: Psychodidae}

\section{Phlebotomus sp.}

\section{Family: Culicidae}

1. Aedes sp.

2. Anopheles sp.

3. Culex sp.

Family: Chironomidae

1. Chironomas sp.

Family: Cecidomyiidae

1. Clenodiplosispongamiae

2. Dasineuracitri

3. Dasineura sesame

4. Lasiopteraachyranthesae

5. Lasiopteratomentosae

Family: Tabanidae

1. Tabanus sp.

2. Tabanus viva

Family: Asilidae

1. Leptogaster sp.

2. Asilus sp.

Family: Trypetidae

1. Bactrocera sp.

2. Dacuscucurbitae

3. Dacusdorsalis 


\section{Family: Agromyzidae}

1. Agromyzha sp.

Family: Drosphilidae

1. Drosophilla melanogaster

Family: Muscidae

1. Muscadomestica

2. Muscanebulo

Family: Anthomyiidae

1. Hylemyabrassicae

2. Limnophora sp.

3. Spilogaster sp.

Family: Calliphoridae

1. Calliphoracrythrocephala

2. Calliphora sp.

3. Chrysomyamegacephala

4. Chrysomya sp.

5. Lucilia sp.

Family: Sarcophagidae

1. Sarcophaga sp.

Family: Tachinidae

Blepharipazebiana

Family: Oestridae

1. Pyragra sp.

Family: Hippobiscidae

1. Hippobosca equine

2. Hippobosca sp.

\section{References}

Grimaldi, D. A. \& Engel, M. S. (2005):
Evolution of the insects. Cambridge University Press, New York.

Kumar, B. Y. S. and Vijayan, V. A. (2005): Mosquito fauna and breeding habitats in the rural areas of Mysore and Mandya Districts, Karnataka State, India. Entomon, 30 (2): 123-129.

Mariappan, T., Arunachalam, N., Somachary, N. and Reddy, C. M. R. (1997): A note on the Dipteran fauna of Kochi and its adjoining Islands in Kerala. Entomon, 22 (2): 141-145.

Nandi, B. C. (1990): Sarcophagid flies (Diptera: Sarcophagidae) from Tamil Nadu and Kerala, India. Records of Zoological Survey of India, 87 (2): 151155.

Rajput, K. B. and Kulkarni, S. M. (1990): Records of culicine mosquitoes from Bastar District (Madhya Pradesh (Diptera: Culicidae). Records ofZoological Survey of India, 87 (1): 8388.

Ranganath, H. R. and Veenakumari, K. (1996): Some new records of fruit flies (Diptera: Tephritidae) from the Andaman and Nicobar Islands. Entomon, 21 (1): 95-97.

Sharma, A.; Sharma, R. C. and Anthwal, A. (2008): Surveying of aquatic insect diversity of Chandrabhaga river, Garhwal, Himalayas. Environmentalist, 28: 395-404.

Tingare, B. P. (2007): Taxonomy of mosquitoes from Southern Maharashtra. Ph. D. thesis submitted to Shivaji University, Kolhapur.

\section{How to cite this article:}

Bharamal, D. L., 2016 .A Preliminary survey of Dipterans in Sindhudurg District, Maharashtra, India. Int.J.Curr.Microbiol.App.Sci. 5(1): 396-398.'inttp://dx.doi.org/10.20546/ijcmas. 2016.501 .1 .038 